Proceedings of the Institution of
Civil Engineers
Waste and Resource Management
163
May 2010 Issue WR2
Pages $59-66$
doi: $10.1680 /$ warm.2010.163.2.59
Paper 900011
Received $18 / 03 / 2009$
Accepted 09/12/2009
Keywords:
concrete structures/environment/
recycling \& reuse of materials
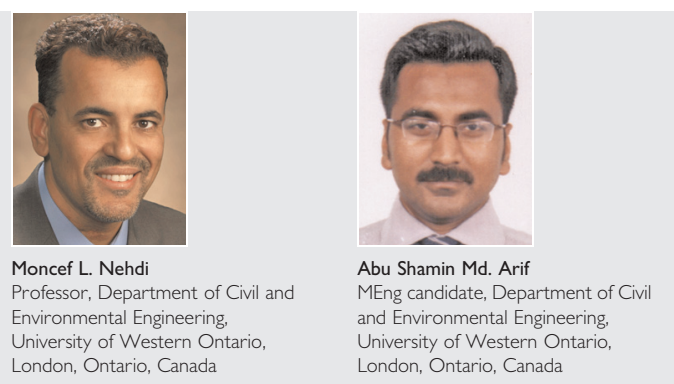

\title{
Paintcrete leachability in fresh water and marine environments
}

\author{
M. L. Nehdi PhD, PEng and A. S. M. Arif MEng, EIT
}

Waste latex paint is considered the largest (by volume) household liquid hazardous waste collected in Canada and the USA. A technology for recycling latex paint in Portland cement concrete with added value was developed at The University of Western Ontario. The present study investigates the leaching of hazardous species from concrete incorporating recycled paint, known as 'paintcrete' as a partial replacement for mixing water. Specimens from concrete mixtures with various proportions of paint were subjected to simulated field environments including freezing-thawing and wetting-drying cycles, both in fresh and simulated seawater. The leachates from these specimens were analysed for heavy metals and glycols. It was found that the leaching of heavy metals from concrete specimens incorporating 15-25\% paint and subjected to wetting-drying and freezing-thawing cycles, either in fresh water or artificial seawater, was not significant compared with values measured for a reference concrete mixture with no paint. The leaching concentrations of heavy metals were well below the contaminant levels according to the hazardous waste regulatory limits. In addition, glycol concentrations in the leachates at the end of a total of 100 cycles of freezing-thawing were much lower than the concentration of glycols in the original paint. Glycol leachates were also found to be acceptable based on environmental guidelines for glycols in surface water.

\section{INTRODUCTION}

Polymer-modified concrete has been used in diverse applications owing to its improved tensile, flexural and bond strength, shock resistance, abrasion resistance and watertightness. Various types of polymer-modified concretes and mortars have been produced with latex monomers, liquid resins, water-soluble resins and powdered emulsions. Yang et al. (1993) investigated the effects of polymer latex addition on the properties of solidified mercurycontaining sludge. The addition of polymer latex resulted in a greater compressive strength and much lower mercury concentration in the toxicity characteristics leaching procedure (US EPA, 1992) leachate when the solidified specimens were subjected either to freezing-thawing or wetting-drying ageing. Zampori et al. (2006) studied the role of polymeric additives (styrene-butadiene rubber latex or a superplasticiser based on acrylic-modified polymer) on the hydration process of cement pastes admixed with a lead compound $\left(\mathrm{Pb}_{3} \mathrm{O}_{4}\right)$. Dynamic leaching tests on the solidified monolith revealed that latex addition achieved an excellent capacity to hold $\mathrm{Pb}_{3} \mathrm{O}_{4}$ within the matrix after $384 \mathrm{~h}$ of leaching.

A study on the fresh, mechanical and durability properties of Portland cement concrete mixtures incorporating various proportions of waste latex paint (WLP) as a partial replacement for mixing water provided positive results (Mohammed et al., 2008). The initial setting time of the concrete was not reduced due to the addition of WLP; the final setting was slightly reduced, which is perceived as an advantage. Concrete incorporating WLP was less vulnerable to curing regime than is conventional concrete. The compressive strength decreased with WLP addition, but the flexural strength increased. WLP concrete exhibited an increased resistance to rapid chloride ion penetration, surface scaling by deicing salts and sulfuric acid, along with an improved durability to rapid freezing-thawing cycles.

However, there is some concern regarding the environmental impact of using WLP in cement-based materials since WLP may include biocides, heavy metals and solvents such as ethylene glycol and glycol ethers. The main concern with respect to the environmental impact of 'paintcrete' (concrete incorporating WLP) is therefore the leaching of heavy metals and solvents under various exposure conditions such as freezing-thawing and wetting-drying cycles in fresh and salt water. Such hostile field exposure of concrete can be simulated in the laboratory using accelerated ageing in fresh (tap water) and artificial seawater (simulated marine environment). Therefore, this study on the leachability of paintcrete was carried out. This work is required before recommending full-scale implementation of recycling WLP in concrete, especially as potential projects for this practice include fish reefs and waterfront municipal structures.

\section{EXPERIMENTAL PROGRAMME}

\section{I. Materials}

The materials used in this study include ordinary Portland cement ASTM C150 Type 1, (ASTM, 2009) ground granulated blastfurnace slag, siliceous gravel coarse aggregates with a maximum nominal size of $10 \mathrm{~mm}$, siliceous sand, an air-entraining admixture (Micro-air product of Degussa Admixtures Inc.) and a water-reducing admixture (ADVA 140 product of WR Grace Chemicals). The WLP used in the concrete mixtures was obtained from the waste collection site of the City of London, Ontario. The metal and metalloid components and glycols present in the WLP are presented in Tables 1 and 2. 


\begin{tabular}{llllllllllll}
$\mathrm{Al}$ & $\mathrm{Ba}$ & $\mathrm{Cr}$ & $\mathrm{Cu}$ & $\mathrm{Fe}$ & $\mathrm{Mg}$ & $\mathrm{Mn}$ & $\mathrm{Ni}$ & $\mathrm{Sr}$ & $\mathrm{Sn}$ & $\mathrm{Ti}$ & $\mathrm{Zn}$ \\
\hline 6000 & 18 & 0.6 & 56 & 2800 & 200 & 4 & 0.9 & 3 & 2 & 410 & 120
\end{tabular}

Table I. Concentration $(\mu \mathrm{g} / \mathrm{g})$ of metals in WLP by axial ICP-AES (methods W846 60I0C (US EPA, 2007) (wet basis)

\subsection{Experimental procedure}

Concrete mixtures with a water/binder ratio $(\mathrm{w} / \mathrm{b})$ of $0 \cdot 40$ incorporating 0, 15 and 25\% of WLP as a partial replacement for mixing water were made according to ASTM C192 guidelines (ASTM, 2006). A concrete mixture incorporating no WLP was taken as the reference. The mixture proportions for the various mixtures are shown in Table 3. Water and WLP were first mixed manually. Saturated and surface-dried coarse aggregates were then mixed with part of the mixing water (containing WLP). Fine aggregates and cementitious materials were then added and mixing resumed for $2 \mathrm{~min}$ with the remaining mixing water and chemical admixtures being added over the first minute of mixing. After a 2 min rest period, a 3 min mixing sequence was conducted, and the mixer was then covered with plastic sheeting to prevent evaporation (Ramakrishhnan, 1992).

Being a waste material, WLP is subject to high variability of its water and solid contents. It is recommended that WLP be bulked in systems equipped with continuous stirring to prevent segregation. A quality control programme needs to be enforced and subsequent adjustments to concrete mix design need to be performed in order to maintain consistency of paintcrete production on an industrial scale.

For all mixtures, $75 \times 75 \times 285 \mathrm{~mm}$ prisms and $75 \times 75 \times 75 \mathrm{~mm}$ cubes were cast and covered with wet burlap for $24 \mathrm{~h}$. Specimens were subsequently de-moulded; the prism specimens were aircured under laboratory conditions at around $23^{\circ} \mathrm{C}$ and $50 \pm 5 \%$ $\mathrm{RH}$ (relative humidity), while the cube specimens were wrapped in polythene sheets and placed in sealed containers to prevent evaporation of glycols until the start of ageing.

2.2.1. Ageing under freeze-thaw cycling. ASTM C666 procedure (ASTM, 2003) was used for the freezing-thawing conditioning of the $75 \times 75 \times 285 \mathrm{~mm}$ concrete prism specimens. A total of 12 specimens (four replicates for each of the three concrete mixtures incorporating 0, 15 and 25\% WLP) were subjected to freeze-thaw ageing in an automated freeze-thaw cabinet (Figure 1). Half of the specimens were placed in the freeze-thaw chambers containing fresh water, and the other half were in chambers containing artificial seawater of salinity $31.3 \mathrm{ppt}$ (parts per thousand) at $21^{\circ} \mathrm{C}$ prepared as per SOP TA-03.02-5.10 guidelines (Faircloth, 2007). Each chamber contained equal amounts of fresh (tap water) or

\begin{tabular}{|lcccc|}
\hline $\begin{array}{l}\text { Diethylene } \\
\text { glycol }\end{array}$ & $\begin{array}{c}\text { Ethylene } \\
\text { glycol }\end{array}$ & $\begin{array}{c}\text { Propylene } \\
\text { glycol }\end{array}$ & $\begin{array}{c}\text { Total } \\
\text { glycols }\end{array}$ & $\mathrm{RDL}^{*}$ \\
\hline Not detected & 36000 & 9100 & 45100 & 5000 \\
\hline
\end{tabular}

${ }^{*}$ Reportable detection limit

Table 2. Concentration $(\mu \mathrm{g} / \mathrm{g})$ of glycols in WLP by GC-FID (TCLP method 8015 (US EPA, 1992)

\begin{tabular}{|lccc|}
\hline & \multicolumn{3}{c|}{ Waste latex paint: \% } \\
\cline { 2 - 4 } & 0 & 15 & 25 \\
\hline & 280 & 280 & 280 \\
Cement: $\mathrm{kg} / \mathrm{m}^{3}$ & 70 & 70 & 70 \\
Slag: $\mathrm{kg} / \mathrm{m}^{3}$ & 350 & 350 & 350 \\
Total cementitious materials: $\mathrm{kg} / \mathrm{m}^{3}$ & 0 & 21 & 35 \\
Waste latex paint: $\mathrm{kg} / \mathrm{m}^{3}$ & 140 & 130 & 122 \\
Total water: $\mathrm{kg} / \mathrm{m}^{3 *}$ & $0 \cdot 40$ & 0.37 & 0.35 \\
Water/binder ratio & 0 & 0.9 & 1.5 \\
Polymer/cement ratio: \% & 1050 & 1050 & 1050 \\
Coarse aggregate: $\mathrm{kg} / \mathrm{m}^{3}$ & 750 & 750 & 750 \\
Fine aggregate: $\mathrm{kg} / \mathrm{m}^{3}$ & 235 & 235 & 235 \\
Water-reducing agent: $\mathrm{ml} / \mathrm{l} 00 \mathrm{~kg}$ & & & \\
binder & 20 & 20 & 20 \\
Air-entraining admixture: $\mathrm{ml} / 100 \mathrm{~kg}$ & 20 & & \\
binder & & & \\
\hline
\end{tabular}

* Includes the water from WLP

Table 3. Concrete mixture proportions for partially replacing mixing water with WLP

artificial seawater. The specimens in the cabinet were subjected to a temperature variation of 10 to $-7^{\circ} \mathrm{C}$ at a rate of five cycles per day; 300 freezing-thawing cycles were conducted in total. The solutions in which the different specimens from the various WLP concrete mixtures were aged were collected after 75, 175 and 300 freeze-thaw cycles, and chemical analyses for heavy metals using ICP-AES (inductively coupled plasma atomic emission spectroscopy) were conducted.

Leaching tests for glycols were conducted on paintcrete specimens incorporating 15\% WLP. The test consisted of measuring the mobility of glycols (ethylene glycol and glycol ethers) from 15\% WLP concrete cube specimens at 7, 28 and 56 days after casting according to TCLP method 8015 (US EPA, 1992) using a gas chromatograph-flame ionisation detector (GC-FID). Special measures were taken to control the evaporation of glycols from the 15\% WLP concrete cube specimens by wrapping them securely with polyethylene sheets and storing the specimens in airtight containers until the start of each test. In addition, four 15\% WLP concrete cube specimens were subjected to 100 cycles of

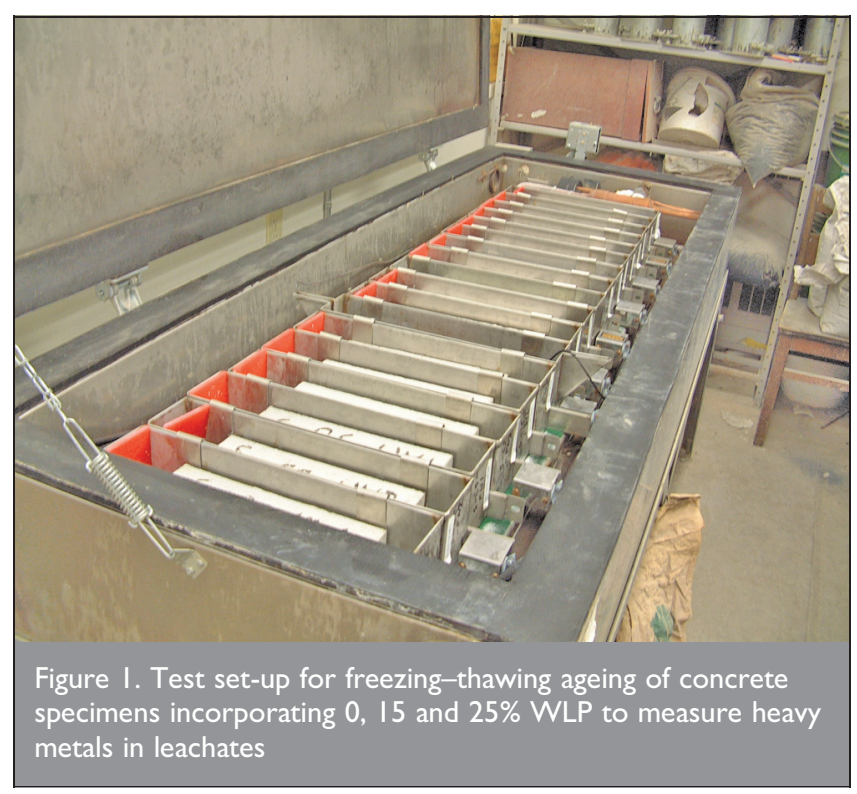


freezing-thawing ageing (five cycles per day) either in fresh water or artificial seawater. Each specimen was placed in an airtight container with equal amounts of fresh (tap water) or artificial seawater. The same artificial seawater prepared as per SOP TA03.02-5.10 guidelines (Faircloth, 2007) was used. Half of the specimens were aged in artificial seawater and the other half in tap water. At the end of ageing, leachates (solutions in which cube specimens were aged) were collected and analysed for glycols using GC-FID.

\subsubsection{Ageing under wetting-drying cycles. The wetting-drying} ageing used in this study consisted of a total of 50 cycles. Each cycle included one day of wetting either in fresh water or artificial seawater and one day of drying in an automated walk-in environmental chamber maintained at $40^{\circ} \mathrm{C}$ and $40 \%$ RH. Six containers (three for fresh and three for artificial seawater) were used for the wetting cycles for the different specimens. Each container contained two replicate specimens from each mixture and equal amounts of either fresh or artificial seawater. Artificial seawater of salinity $31.7 \mathrm{ppt}$ at $19 \cdot 5^{\circ} \mathrm{C}$ was prepared as per SOP TA-03.02-5.10 guidelines (Faircloth, 2007). At the end of 10, 20, 30,40 and 50 cycles, samples of the solutions in which the different specimens were aged were collected and analysed for heavy metals using ICP-AES.

\subsubsection{Standard leaching test on aged specimens. Standard} leaching tests were conducted using TCLP test method 1311 (US EPA, 1992) on aged (wetting-drying and freezing-thawing) specimens from concrete mixtures incorporating 0, 15 and 25\% WLP. The test was used to provide an insight; its practicality is in the event that paintcrete is disposed of in landfills after demolition (in a crushed state) or when it is recycled as an aggregate in making concrete pavements. The aged specimens were crushed to reduce the particle size to less than $9.5 \mathrm{~mm}$. The crushed specimens were mixed in an extraction vessel with an acetic acid solution (pH of $2 \cdot 88 \pm 0 \cdot 05$ ) at a mass ratio of $20: 1$. The reason for using acid as an extraction fluid is that paintcrete is expected to be exposed to acidic environments when it is used in animal barns and sewer pipes, comes into contact with acidic soils or is subjected to acid rain after disposal. The vessels were shaken using a wrist-action shaker at $30 \mathrm{rpm}$ for $18 \mathrm{~h}$. The leachate was centrifuged at $2000 \mathrm{rpm}$ for $20 \mathrm{~min}$ to separate solid particles from the liquid using a high-speed centrifuge machine. The leachate obtained was decanted after centrifuge and divided into two portions. One portion was used for $\mathrm{pH}$ measurements and the other for the determination of toxic metals present in the leachate using ICP-AES. Each extraction test was performed on two replicate specimens and the average value noted.

\section{ANALYSES OF HEAVY METALS AND GLYCOLS}

The fresh water and artificial seawater solutions in which the different specimens from various WLP concrete mixtures were aged (50 cycles of wetting-drying and 300 cycles of

freezing-thawing) were filtered to remove particulates and large colloids using a membrane filter. A number of metals of interest including aluminium (Al), copper (Cu), nickel (Ni), manganese $(\mathrm{Mn})$, titanium (Ti), barium (Ba), chromium $(\mathrm{Cr})$ and zinc $(\mathrm{Zn})$ were analysed by means of ICP-AES. For the case of wetting-drying ageing, two replicate specimens from each mixture were immersed in a single container and solutions were collected from each container for analysis. In addition, two replicates of specimens from each mixture for freezing-thawing ageing were placed in two separate chambers and solutions were collected from the two chambers. Average values of the concentrations ( $\mathrm{mg} / \mathrm{l}$ or $\mu \mathrm{g} / \mathrm{g}$ ) were noted.

Standard leaching tests as per TCLP method 1311 (US EPA, 1992) on aged (50 cycles of wetting-drying and 300 cycles of freezing-thawing) concrete specimens for concrete mixtures incorporating 0, 15 and 25\% WLP were carried out. Each extraction test was performed on two replicate specimens and average values of metal concentrations $(\mathrm{mg} / \mathrm{l} \mathrm{or} \mathrm{mg} / \mathrm{kg}$ ) were recorded.

The leachability or the mobility potential of glycols from 15\% WLP concrete cube specimens at 7, 28 and 56 days after casting were conducted according to TCLP method 8015 (US EPA, 1992) by GC-FID. In addition, the concentration of glycols in the leachates at the end of 100 freezing-thawing ageing cycles was measured using GC-FID.

\section{RESULTS AND DISCUSSION}

\section{I. Wetting-drying ageing}

The concentrations of heavy metals that leached from the various concrete mixtures incorporating 0, 15 and 25\% WLP after 10, 20, 30, 40 and 50 cycles of wetting-drying ageing in fresh (tap water) and artificial seawater are shown in Figures 2 and 3, respectively. At the end of 10 drying-wetting cycles, the leaching of aluminium from 0, 15 and 25\% WLP specimens was high compared with that of the other metals both in fresh water and artificial seawater, except for the 15\% WLP specimens. Aluminium leaching decreased substantially for all specimens (0, 15 and 25\% WLP) at the end of 20 drying-wetting cycles, whether in fresh or artificial seawater, probably due to increased cement hydration reactions and decreased permeability of specimens; it became zero at the end of 30, 40 and 50 cycles. Moreover, aluminium leaching, except for the 15\% WLP specimens aged in fresh water, was lower in the 15 and 25\% WLP specimens than that in the reference $0 \%$ WLP specimens at the end of 10 cycles, whether in fresh water or artificial seawater. The aluminium in 0\% WLP is likely from the cement and slag. It is shown that aluminium leaching did not exceed $2.5 \mu \mathrm{g} / \mathrm{g}(3.6 \mathrm{mg} / \mathrm{l})$ while its concentration was $6000 \mu \mathrm{g} / \mathrm{g}$ in the original latex paint.

The leaching of zinc from 0, 15 and 25\% WLP concrete specimens lagged by 20 cycles and was observed at the end of 30 drying-wetting cycles both in fresh water and artificial seawater. An increasing trend of zinc concentration was observed between 30 and 40 drying-wetting cycles; it then decreased to almost zero at the end of 50 cycles in the case of wetting in artificial seawater. Moreover, the leached zinc concentrations for 15 and 25\% WLP concrete specimens aged in artificial seawater were less than that of the 0\% WLP specimens at the end of 50 cycles. Little or no increase in zinc concentration between 30 and 50 wetting-drying cycles was observed for all specimens in the fresh water wetting regime.

Increasing trends in the concentrations of both nickel and chromium were observed for the 0, 15 and 25\% WLP concrete specimens from 10 to 40 drying-wetting cycles, while decreasing trends were observed at the end of 50 cycles both in fresh water and artificial seawater. However, the concentrations of leached nickel and chromium for 15 and 25\% WLP concrete at the end of 50 drying-wetting cycles were less than that of the 0\% WLP 


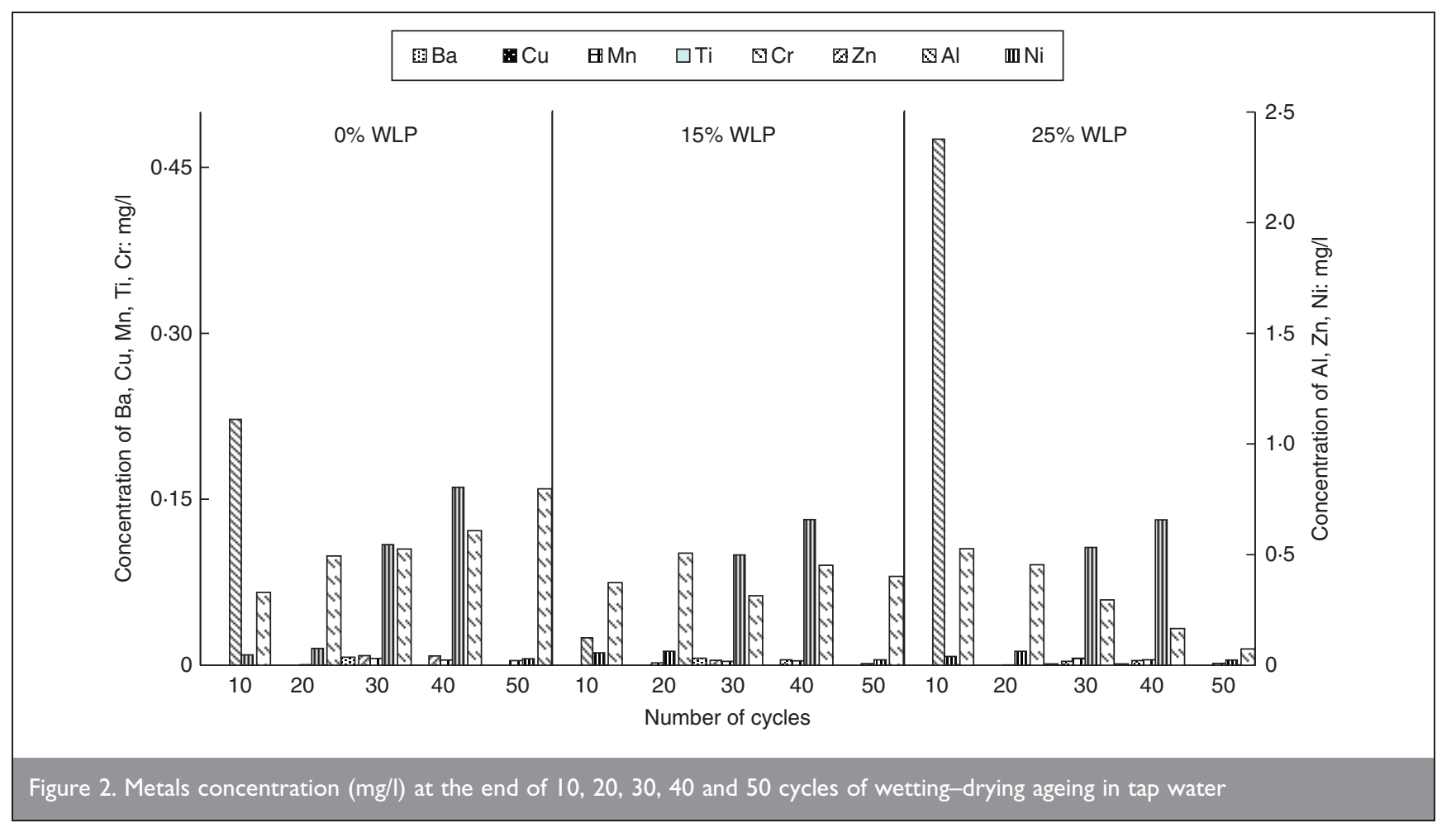

concrete specimens, whether in fresh water or artificial seawater. The drop in the concentrations of leached zinc, nickel and chromium for 15\% and 25\% WLP concrete is an indication of the potential ability of WLP concrete to stabilise trace contaminant metals even under hostile environments involving cyclic drying and wetting.

When wetting was performed in artificial seawater, the zinc, nickel and chromium concentrations for the 0, 15 and 25\% WLP concrete specimens were higher than those when the wetting regime was in fresh water. Although nickel and zinc from the 15 and 25\% WLP concrete specimens initially leached a little more than that of the $0 \%$ WLP concrete (reference mixture), the concentrations became lower than that of the reference concrete at the end of 50 wetting-drying cycles when specimens were aged in artificial seawater. The chromium concentration for 0\% WLP concrete was consistently higher than that for 15 and 25\% WLP concrete aged in artificial seawater.

All other metals in the leachates - that is, manganese, barium and titanium - were effectively in very small concentrations in the leachates.

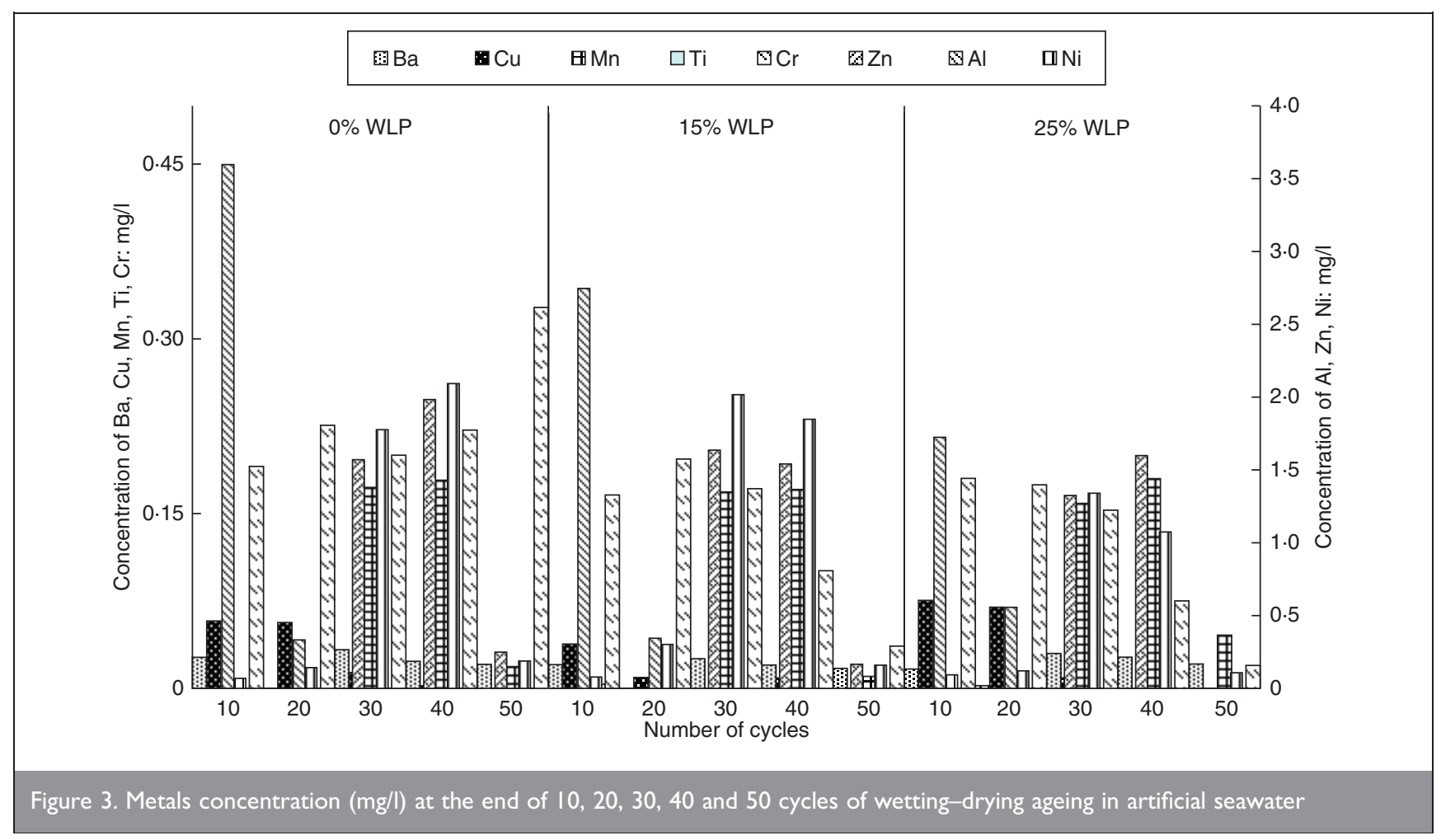




\begin{tabular}{|c|c|c|c|c|c|c|c|c|c|}
\hline \multirow{2}{*}{$\begin{array}{l}\text { No. of } \\
\text { cycles }\end{array}$} & \multirow{2}{*}{$\begin{array}{c}\text { WLP: } \\
\%\end{array}$} & \multicolumn{8}{|c|}{ Concentration: mg/l (mg/kg) } \\
\hline & & Al & $\mathrm{Ba}$ & $\mathrm{Cr}$ & $\mathrm{Cu}$ & $M n$ & $\mathrm{Ni}$ & $\mathrm{Ti}$ & $\mathrm{Zn}$ \\
\hline 75 & $\begin{array}{r}0 \\
15\end{array}$ & $\begin{array}{c}1.44 \mid 4 \\
(1.5035) \\
2.6344 \\
(2.7395) \\
1.0339 \\
(1.0783)\end{array}$ & $\begin{array}{c}0.2572 \\
(0.2622) \\
\mid .2906 \\
(\mid \cdot 3628) \\
0.7972 \\
(0.8272)\end{array}$ & $\begin{array}{c}0.11111 \\
(0.1159) \\
0.0696 \\
(0.0727) \\
0.0548 \\
(0.0571)\end{array}$ & $\begin{array}{l}<\mathrm{RDL}^{*} \\
<\mathrm{RDL}^{*} \\
<\mathrm{RDL}^{*}\end{array}$ & $\begin{array}{c}<\mathrm{RDL}^{*} \\
0.0008 \\
(0.0008) \\
<\mathrm{RDL}^{*}\end{array}$ & $\begin{array}{c}0.0035 \\
(0.0037) \\
0.01112 \\
(0.0116) \\
0.0002 \\
(0.0002)\end{array}$ & $\begin{array}{c}0.0019 \\
(0.0020) \\
0.0006 \\
(0.0006) \\
0.0002 \\
(0.0002)\end{array}$ & $\begin{array}{l}<\mathrm{RDL} \dagger \\
<\mathrm{RDL} \dagger \\
<\mathrm{RDL} \dagger\end{array}$ \\
\hline 175 & $\begin{array}{l}0 \\
15 \\
25\end{array}$ & $\begin{array}{c}4.3285 \\
(4.4429) \\
5.5795 \\
(5.8154) \\
3.4379 \\
(3.5503)\end{array}$ & $\begin{array}{c}0.0021 \\
(0.002 I) \\
0.0065 \\
(0.0066) \\
0.0585 \\
(0.0618)\end{array}$ & $\begin{array}{c}0.2197 \\
(0.2256) \\
0.1862 \\
(0.1936) \\
0.0952 \\
(0.0984)\end{array}$ & $\begin{array}{c}0.0223 \\
(0.0232) \\
0.1130 \\
(0.1178) \\
0.0562 \\
(0.0591)\end{array}$ & $\begin{array}{c}0.0058 \\
(0.0059) \\
0.0060 \\
(0.0064) \\
0.0063 \\
(0.0064)\end{array}$ & $\begin{array}{c}0.3559 \\
(0.3629) \\
0.1325 \\
(0.1395) \\
0.0863 \\
(0.0883)\end{array}$ & $\begin{array}{c}0.0006 \\
(0.0006) \\
0.0019 \\
(0.0019) \\
0.0010 \\
(0.0011)\end{array}$ & $\begin{array}{c}0.0309 \\
(0.03 \mid 4) \\
0.0205 \\
(0.02 । 4) \\
0.0268 \\
(0.0276)\end{array}$ \\
\hline 300 & $\begin{array}{l}0 \\
15 \\
25\end{array}$ & $\begin{array}{c}5 \cdot 4309 \\
(5 \cdot 6501) \\
4.6850 \\
(4.8603) \\
2 \cdot 0104 \\
(2 \cdot 1002)\end{array}$ & $\begin{array}{c}0.0207 \\
(0.0217) \\
0.0613 \\
(0.0641) \\
0.2276 \\
(0.2397)\end{array}$ & $\begin{array}{c}0.2404 \\
(0.2503) \\
0.1626 \\
(0.1683) \\
0.0778 \\
(0.0816)\end{array}$ & $\begin{array}{c}0.0223 \\
(0.0232) \\
0.2202 \\
(0.2298) \\
0.0562 \\
(0.0591)\end{array}$ & $\begin{array}{c}0.0060 \\
(0.0063) \\
0.0096 \\
(0.0100) \\
0.0085 \\
(0.0090)\end{array}$ & $\begin{array}{c}0.5710 \\
(0.5963) \\
0.1006 \\
(0.1051) \\
0.0248 \\
(0.0260)\end{array}$ & $\begin{array}{c}0.0006 \\
(0.0006) \\
0.0007 \\
(0.0008) \\
0.0011 \\
(0.0012)\end{array}$ & $\begin{array}{c}0.0134 \\
(0.0140) \\
0.0383 \\
(0.0400) \\
0.0246 \\
(0.0257)\end{array}$ \\
\hline
\end{tabular}

\subsection{Freezing-thawing ageing}

4.2.1. Leaching of heavy metals. The concentration of heavy metals leached from specimens from the various concrete mixtures incorporating 0,15 and 25\% WLP after 75, 175 and 300 cycles of freezing-thawing ageing in fresh (tap water) and artificial seawater are shown in Tables 4 and 5, respectively.
The leaching of aluminium, chromium and nickel showed an increasing trend for 0\% WLP concrete specimens between 75 and 300 freezing-thawing cycles. Conversely, the leaching trend increased from 75 to 175 cycles and decreased from 175 to 300 freezing-thawing cycles for the 15 and 25\% WLP concrete specimens aged in fresh water. There was little or no increase in aluminium concentration for the 0\% WLP concrete, but an

\begin{tabular}{|c|c|c|c|c|c|c|c|c|c|}
\hline \multirow{2}{*}{$\begin{array}{l}\text { No. of } \\
\text { cycles }\end{array}$} & \multirow{2}{*}{$\begin{array}{c}\text { WLP: } \\
\%\end{array}$} & \multicolumn{8}{|c|}{ Concentration: mg/l (mg/kg) } \\
\hline & & Al & $\mathrm{Ba}$ & $\mathrm{Cr}$ & $\mathrm{Cu}$ & $M n$ & $\mathrm{Ni}$ & $\mathrm{Ti}$ & $\mathrm{Zn}$ \\
\hline 75 & $\begin{array}{l}0 \\
15 \\
25\end{array}$ & $\begin{array}{c}0.1316 \\
(0.0942) \\
0.2063 \\
(0.2094) \\
<\text { RDL }^{*}\end{array}$ & $\begin{array}{c}1.4164 \\
(1.0226) \\
0.3464 \\
(0.3516) \\
0.0390 \\
(0.0394)\end{array}$ & $\begin{array}{c}0.0705 \\
(0.0507) \\
0.0298 \\
(0.0302) \\
0.0031 \\
(0.0031)\end{array}$ & $\begin{array}{c}0.0427 \\
(0.0372) \\
<R D L \dagger \\
0.0026 \\
(0.0026)\end{array}$ & $\begin{array}{l}<\mathrm{RDL} \dagger \\
<\mathrm{RDL} \dagger \\
<\mathrm{RDL} \dagger\end{array}$ & $\begin{array}{c}0.0129 \\
(0.0105) \\
0.0084 \\
(0.0085) \\
0.0049 \\
(0.0050)\end{array}$ & $\begin{array}{l}<\mathrm{RDL} \ddagger \\
<\mathrm{RDL} \ddagger \\
<\mathrm{RDL} \ddagger\end{array}$ & $\begin{array}{c}0.0735 \\
(0.0739) \\
0.0212 \\
(0.0215) \\
0.0169 \\
(0.0171)\end{array}$ \\
\hline 175 & $\begin{array}{l}0 \\
15 \\
25\end{array}$ & $\begin{array}{c}0.1394 \\
(0.1239) \\
1.5190 \\
(1.3122) \\
0.9425 \\
(0.8216)\end{array}$ & $\begin{array}{c}2.2913 \\
(1.9718) \\
2.4071 \\
(2.0186) \\
3.0048 \\
(2.5751)\end{array}$ & $\begin{array}{c}0.3317 \\
(0.2866) \\
0.2592 \\
(0.2205) \\
0.5416 \\
(0.4665)\end{array}$ & $\begin{array}{c}0.1700 \\
(0.1447) \\
0.2016 \\
(0.1697) \\
0.2699 \\
(0.2317)\end{array}$ & $\begin{array}{c}0.2758 \\
(0.2406) \\
0.3460 \\
(0.294 I) \\
0.3573 \\
(0.3087)\end{array}$ & $\begin{array}{c}0.3724 \\
(0.3231) \\
0.4414 \\
(0.3750) \\
0.5544 \\
(0.4818)\end{array}$ & $\begin{array}{c}0.0157 \\
(0.0139) \\
<\text { RDL } \ddagger \\
\\
0.0054 \\
(0.0047)\end{array}$ & $\begin{array}{c}2.7515 \\
(2.3842) \\
2.8298 \\
(2.4091) \\
2.4048 \\
(2.0834)\end{array}$ \\
\hline 300 & $\begin{array}{l}0 \\
15 \\
25\end{array}$ & $\begin{array}{c}0.1394 \\
(0.1239) \\
1.5190 \\
(1.3122) \\
3.2207 \\
(2.7643)\end{array}$ & $\begin{array}{c}2.9648 \\
(2.557 I) \\
1.9399 \\
(1.6313) \\
2.2053 \\
(1.8846)\end{array}$ & $\begin{array}{c}0.3292 \\
(0.2860) \\
0.2817 \\
(0.2396) \\
0.6868 \\
(0.5891)\end{array}$ & $\begin{array}{c}0.2010 \\
(0.1722) \\
0.2048 \\
(0.1727) \\
0.3384 \\
(0.2894)\end{array}$ & $\begin{array}{c}0.3188 \\
(0.2780) \\
0.3360 \\
(0.2861) \\
0.3929 \\
(0.3384)\end{array}$ & $\begin{array}{c}0.3216 \\
(0.2813) \\
0.3491 \\
(0.2981) \\
0.7492 \\
(0.6476)\end{array}$ & $\begin{array}{c}0.0157 \\
(0.0139) \\
<\text { RDL } \ddagger \\
<\text { RDL } \ddagger\end{array}$ & $\begin{array}{c}2.7752 \\
(2.4156) \\
2.9152 \\
(2.4831) \\
3.5222 \\
(3.0336)\end{array}$ \\
\hline
\end{tabular}




\begin{tabular}{|c|c|c|c|c|c|}
\hline & \multicolumn{5}{|c|}{ Concentration: mg/kg } \\
\hline & Diethylene glycol & Ethylene glycol & Propylene glycol & Total glycols & $\mathrm{RDL}^{*}$ \\
\hline 7-day cured sample & 15 & 270 & 75 & 360 & 10 \\
\hline 28-day cured sample & 14 & 190 & 51 & 255 & 10 \\
\hline 56-day cured sample & 12 & 120 & 33 & 165 & 10 \\
\hline
\end{tabular}

\begin{tabular}{|c|c|c|c|c|c|}
\hline & \multicolumn{5}{|c|}{ Concentration: mg/l } \\
\hline & Diethylene glycol & Ethylene glycol & Propylene glycol & Total glycols & $\operatorname{RDL} \dagger$ \\
\hline After ageing in fresh (tap) water & $N D^{*}$ & 48 & 12 & 60 & 5 \\
\hline After ageing in artificial seawater & ND & 52 & 13 & 65 & 5 \\
\hline \multicolumn{6}{|l|}{$\begin{array}{l}{ }^{*} \text { Not detected } \\
\dagger \text { Reportable detection limit }\end{array}$} \\
\hline
\end{tabular}

increasing trend was observed for the 15 and 25\% WLP specimens when the ageing regime was in artificial seawater. When the freezing-thawing cycles were carried out in artificial seawater, the increase in chromium and nickel concentrations between 75 and 300 cycles was comparable for the 0 and 15\% WLP specimens, and significantly higher for the 25\% WLP specimens.

A decreasing trend in the concentration of barium between 75 and 300 freezing-thawing cycles was observed for the 0, 15 and 25\% WLP specimens aged in fresh water. On the other hand, an increasing trend for barium leaching was observed between 75 and 300 freezing-thawing cycles for the 0\% WLP specimens when aged in artificial seawater. Barium concentrations for the 15 and 25\% WLP samples increased up to 175 cycles and decreased significantly from 175 to 300 cycles when aged in artificial seawater.

For the 0, 15 and 25 WLP concrete specimens aged in fresh water, zinc and manganese leached very little compared with identical specimens aged in artificial seawater, and the concentrations for the different WLP concrete specimens were comparable ( $\sim 2.90 \mathrm{mg} / \mathrm{l}$ for zinc and $\sim 0.30 \mathrm{mg} / \mathrm{l}$ for manganese) at the end of the 300 freezing-thawing cycles.

Generally, the leaching of manganese, chromium, nickel, barium, copper and zinc from the 0,15 and 25 WLP concrete specimens aged in artificial seawater was higher than that from identical specimens aged in fresh water, except for the leaching of nickel from the 0\% WLP concrete specimens aged in fresh water. This is probably due to the observed surface scaling in the 0,15 and 25 WLP specimens. The surface scaling was due to intermittent crystallisation-de-crystallisation of salt and icing-de-icing effects inside pores. It is known that the rate and extent of leaching of metals is dependent on the acidity of the environment. Under a freezing-thawing ageing scheme, the change in $\mathrm{pH}$ could be the reason why some metals were released at the beginning of the test while others showed a time lag.

\subsubsection{Leaching of glycols. The concentration of glycols} (diethylene glycol, ethylene glycol and propylene glycol) in the 15\% WLP concrete specimens cured for 7 days was not significant compared with that of glycols measured in the original latex paint. Moreover, the leaching of glycols dropped significantly for specimens cured for 28 and 56 days (Table 6). This can be partly attributed to the ability of WLP concrete to stabilise glycols. In addition, the concentration of glycols (Table 7) in the leachate was well below the regulatory limits of the Canadian Environmental Protection Act 1994 (CDoE, 1994) for glycols in surface water (Table 8).

\subsection{Standard leaching test on aged specimens}

At the end of the prolonged ageing regimes, TCLP test method 1311 (US EPA, 1992) was conducted on the aged 0, 15 and 25 WLP concrete specimens. The concentrations of heavy metals leached from the specimens at the end of 300 cycles of freezing-thawing and 50 cycles of wetting-drying ageing either in fresh or artificial seawater are shown in Table 9.

The concentrations of metals, both for freezing-thawing and wetting-drying ageing, did not exhibit any clear increasing or

\begin{tabular}{|lccc|}
\hline $\begin{array}{l}\text { Diethylene } \\
\text { glycol: } \mathrm{mg} / \mathrm{l}\end{array}$ & $\begin{array}{c}\text { Ethylene } \\
\text { glycol: } \mathrm{mg} / \mathrm{l}\end{array}$ & $\begin{array}{c}\text { Propylene } \\
\text { glycol: } \mathrm{mg} / \mathrm{l}\end{array}$ & $\begin{array}{c}\text { Total } \\
\text { glycols: } \mathrm{mg} / \mathrm{l}\end{array}$ \\
\hline Not specified & Not specified & Not specified & 100 \\
\hline $\begin{array}{l}\text { Table 8. Canadian Environmental Protection Act } 1994 \\
\text { 1994) } \text { (CDogulatory limits for glycols in surface water }\end{array}$ & \\
\hline
\end{tabular}




\begin{tabular}{|c|c|c|c|c|c|c|c|c|}
\hline & \multirow{2}{*}{$\begin{array}{c}\text { WLP: } \\
\%\end{array}$} & \multicolumn{7}{|c|}{ Concentration: mg/l (mg/kg) } \\
\hline & & Al & $\mathrm{Ba}$ & $\mathrm{Cr}$ & $M n$ & $\mathrm{Ni}$ & $\mathrm{Ti}$ & $\mathrm{Zn}$ \\
\hline F/T FW & 0 & $\begin{array}{c}0.0348 \\
(0.0283)\end{array}$ & $\begin{array}{c}1.4265 \\
(1.1629)\end{array}$ & $\begin{array}{c}0.0079 \\
(0.0064)\end{array}$ & $\begin{array}{c}2.4229 \\
(1.9753)\end{array}$ & $\begin{array}{c}0.1013 \\
(0.0826)\end{array}$ & $\begin{array}{c}0.0025 \\
(0.002 I)\end{array}$ & $\begin{array}{c}0.0822 \\
(0.0670)\end{array}$ \\
\hline F/T FW & 15 & $\begin{array}{c}0.0110 \\
(0.0089)\end{array}$ & $\begin{array}{c}1.0317 \\
(0.8368)\end{array}$ & $\begin{array}{c}0.0055 \\
(0.0044)\end{array}$ & $\begin{array}{c}I .166 \mid \\
(0.9462)\end{array}$ & $\begin{array}{c}0.1014 \\
(0.0824)\end{array}$ & $\begin{array}{c}0.0020 \\
(0.0016)\end{array}$ & $<\operatorname{RDL} \dagger$ \\
\hline $\mathrm{F} / \mathrm{T} \mathrm{FW}$ & 25 & $\begin{array}{c}0.0433 \\
(0.0350)\end{array}$ & $\begin{array}{c}1.3565 \\
(1.0988)\end{array}$ & $\begin{array}{c}0.0073 \\
(0.0059)\end{array}$ & $\begin{array}{c}2.3495 \\
(1.9032)\end{array}$ & $\begin{array}{c}0.0960 \\
(0.0778)\end{array}$ & $\begin{array}{c}0.0025 \\
(0.0021)\end{array}$ & $\begin{array}{c}0.0372 \\
(0.0301)\end{array}$ \\
\hline F/T ASW & 0 & $\begin{array}{c}0.0132 \\
(0.0107)\end{array}$ & $\begin{array}{c}0.8686 \\
(0.7057)\end{array}$ & $\begin{array}{c}0.0049 \\
(0.0040)\end{array}$ & $\begin{array}{c}0.4740 \\
(0.3844)\end{array}$ & $\begin{array}{c}0.0659 \\
(0.0536)\end{array}$ & $\begin{array}{c}0.0014 \\
(0.0012)\end{array}$ & $<\mathrm{RDL} \dagger$ \\
\hline F/T ASW & 15 & $\begin{array}{c}0.0148 \\
(0.0120)\end{array}$ & $\begin{array}{c}0.9766 \\
(0.7892)\end{array}$ & $\begin{array}{c}0.0065 \\
(0.0053)\end{array}$ & $\begin{array}{c}0.7095 \\
(0.5708)\end{array}$ & $\begin{array}{c}0.0534 \\
(0.0430)\end{array}$ & $\begin{array}{c}0.0014 \\
(0.0011)\end{array}$ & $<\mathrm{RDL} \dagger$ \\
\hline F/T ASW & 25 & $\begin{array}{c}0.0208 \\
(0.0168)\end{array}$ & $\begin{array}{c}1.1 \mid 48 \\
(0.9038)\end{array}$ & $\begin{array}{c}0.0055 \\
(0.0045)\end{array}$ & $\begin{array}{c}1.6572 \\
(1.3436)\end{array}$ & $\begin{array}{c}0.1008 \\
(0.0817)\end{array}$ & $\begin{array}{c}0.0019 \\
(0.0015)\end{array}$ & $<\operatorname{RDL} \dagger$ \\
\hline W/D FW & 0 & $\begin{array}{c}0.0399 \\
(0.0324)\end{array}$ & $\begin{array}{c}1.0305 \\
(0.8354)\end{array}$ & $\begin{array}{c}0.0080 \\
(0.0065)\end{array}$ & $\begin{array}{c}2 \cdot 1698 \\
(1.7588)\end{array}$ & $\begin{array}{c}0.0804 \\
(0.065 I)\end{array}$ & $\begin{array}{c}0.0026 \\
(0.0021)\end{array}$ & $\begin{array}{c}0.0817 \\
(0.0662)\end{array}$ \\
\hline W/D FW & 15 & $\begin{array}{c}0.0626 \\
(0.0506)\end{array}$ & $\begin{array}{c}1.0073 \\
(0.8146)\end{array}$ & $\begin{array}{c}0.0082 \\
(0.0066)\end{array}$ & $\begin{array}{c}2.0355 \\
(1.6460)\end{array}$ & $\begin{array}{c}0.0647 \\
(0.0523)\end{array}$ & $\begin{array}{c}0.0024 \\
(0.0019)\end{array}$ & $\begin{array}{c}0.0773 \\
(0.0625)\end{array}$ \\
\hline W/D FW & 25 & $\begin{array}{c}0.0561 \\
(0.0453)\end{array}$ & $\begin{array}{l}|.044| \\
(0.8433)\end{array}$ & $\begin{array}{c}0.0051 \\
(0.004 I)\end{array}$ & $\begin{array}{c}2.2608 \\
(1.8265)\end{array}$ & $\begin{array}{c}0.0771 \\
(0.0623)\end{array}$ & $\begin{array}{c}0.0028 \\
(0.0022)\end{array}$ & $\begin{array}{c}0.0759 \\
(0.0613)\end{array}$ \\
\hline W/D ASW & 0 & $\begin{array}{c}0.1180 \\
(0.0954)\end{array}$ & $\begin{array}{c}0.9890 \\
(0.8002)\end{array}$ & $\begin{array}{c}0.0095 \\
(0.0077)\end{array}$ & $\begin{array}{c}2.0524 \\
(1.6609)\end{array}$ & $\begin{array}{c}0.0671 \\
(0.0543)\end{array}$ & $\begin{array}{c}0.0021 \\
(0.0017)\end{array}$ & $\begin{array}{c}0.0937 \\
(0.0758)\end{array}$ \\
\hline W/D ASW & 15 & $\begin{array}{c}0.0445 \\
(0.0360)\end{array}$ & $\begin{array}{c}0.9660 \\
(0.7809)\end{array}$ & $\begin{array}{c}0.0096 \\
(0.0077)\end{array}$ & $\begin{array}{c}2.2198 \\
(1.7944)\end{array}$ & $\begin{array}{c}0.0810 \\
(0.0655)\end{array}$ & $\begin{array}{c}0.0021 \\
(0.0017)\end{array}$ & $\begin{array}{c}0.0761 \\
(0.0615)\end{array}$ \\
\hline W/D ASW & 25 & $\begin{array}{c}0.0329 \\
(0.0266)\end{array}$ & $\begin{array}{c}1.0323 \\
(0.834 I)\end{array}$ & $\begin{array}{c}0.0063 \\
(0.005 \mathrm{I})\end{array}$ & $\begin{array}{c}2.3765 \\
(1.9201)\end{array}$ & $\begin{array}{c}0.0760 \\
(0.0614)\end{array}$ & $\begin{array}{c}0.0033 \\
(0.0027)\end{array}$ & $\begin{array}{c}0.0700 \\
(0.0565)\end{array}$ \\
\hline $\begin{array}{l}{ }^{*} \text { Based on } 20 \\
\dagger \text { Reportable }\end{array}$ & chate li & CLF metn & (US EF & & & & & \\
\hline
\end{tabular}

\begin{tabular}{|c|c|c|c|c|c|c|c|c|c|c|}
\hline As & $\mathrm{Ba}$ & $\mathrm{Cd}$ & $\mathrm{Cr}$ & $\mathrm{Pb}$ & $\mathrm{Ag}$ & $\mathrm{Hg}$ & $\mathrm{Zn}$ & $\mathrm{Cu}$ & $\mathrm{Ti}$ & Mn \\
\hline $5 \cdot 0$ & $100 \cdot 0$ & $1 \cdot 0$ & $5 \cdot 0$ & $5 \cdot 0$ & $5 \cdot 0$ & 0.2 & $N S^{*}$ & NS & NS & NS \\
\hline \multicolumn{11}{|c|}{ * Not specified by US EPA } \\
\hline $\begin{array}{l}\text { Tab } \\
\text { hea }\end{array}$ & $\begin{array}{l}\text { e } 10 . \text { U } \\
\text { y metal }\end{array}$ & $\begin{array}{l}S \text { EPA } \\
\text { S (US }\end{array}$ & EPA, & $\begin{array}{l}\text { dous } \\
\text { 1976) }\end{array}$ & & & & & & \\
\hline
\end{tabular}

decreasing trend for any particular concrete mixture, whether aged in fresh (tap water) or artificial seawater. However, the levels of toxic metals leached from the specimens were acceptable according to United States Environmental Protection Agency regulations summarised in Table 10 (US EPA, 1976). The $\mathrm{pH}$ values of different leachates from the concrete specimens incorporating 0,15 and 25 WLP using acetic acid as the leaching liquid were generally around $6 \cdot 2$.

\section{CONCLUSIONS}

(a) The leaching of heavy metals from concrete incorporating waste latex paint (WLP) as a partial replacement for mixing water under exposure conditions of freezing-thawing and wetting-drying cycles in fresh water and artificial seawater (simulated marine environments) was investigated.

Generally, the leaching of heavy metals was higher when freezing-thawing or wetting-drying was carried out in artificial seawater than in fresh (tap) water. (b) The concentrations of heavy metals leached from 15 and 25\% WLP concrete specimens were well below the limit of contaminant levels according to hazardous waste regulations (US EPA, 1976). Incorporating WLP in concrete specimens did not enhance the leaching of heavy metals, whether in fresh or artificial seawater, even under severe exposure to a total of 50 wetting-drying and 300 freezing-thawing cycles.

(c) Standard leaching tests were carried out in order to check the further potential mobility of heavy metals remaining in the WLP concrete specimens after ageing. It was shown that the release of heavy metals meets US EPA guidelines for hazardous waste.

(d) The leaching of glycols from 15\% WLP concrete specimens at the end of 7, 28 and 56 days of curing decreased with curing age. Moreover, the concentrations of glycols in leachates (solutions in which 15\% WLP specimens were aged either in fresh water or artificial seawater at the end of a total of 100 cycles of freezing-thawing ageing) meet Canadian Environmental Protection Act 1994 (CDoE, 1994) guidelines for glycols in surface water.

(e) The nature of deterioration mechanisms of concrete subjected either to freezing-thawing or wetting-drying ageing schemes is quite different, as is the leaching trend. Drying-wetting cycles can cause micro-cracking and (at times) leaching of lime, which increases porosity and permeability. On the other hand, freezing-thawing cycles can cause severe damage to the microstructure of concrete, turning it into mush when adequate protective measures (e.g. air-entraining admixtures) have not been used. 
The leaching of heavy metals from 15 and 25\% WLP concrete specimens subjected to severe wetting-drying and freezing-thawing ageing cycles either in fresh water or artificial seawater was not significant compared with values measured in the control reference mixture with no WLP, indicating that leaching is mainly from the cementitious matrix itself. In addition, using WLP in concrete as a partial replacement for mixing water did not only limit the leaching of heavy metals and glycols from WLP concrete specimens but also contributed to stabilising additional trace metals present in the cement and slag used in making the concrete. It is generally believed that the pore-blocking effect provided by the polymer content of WLP and the micro-fillers used as extenders in the original paint reduce fluid transport and ionic diffusion in the concrete and thus reduce leaching.

\section{ACKNOWLEDGEMENT}

The second phase of the research was funded by the Okaloosa County, Florida and Florida DEP.

\section{REFERENCES}

ASTM (American Society for Testing and Materials) (2003) Standard Test Method for Resistance of Concrete to Rapid Freezing and Thawing. ASTM, West Conshohocken, PA, ASTM C666: Vol. 04.02.

ASTM (2006) Standard Practice for Making and Curing Concrete Test Specimens in the Laboratory. ASTM, West Conshohocken, PA, ASTM C192: Vol. 04.02.

ASTM (2009) Standard Specification for Portland Cement. ASTM, West Conshohocken, PA, ASTM C150-09.
CDoE (Canadian Department of the Environment) (1994) Canadian Environmental Protection Act 1994: Section 53. Order in Council, P.C. 1994-106. CDoE, Quebec, Canada.

Faircloth JM (2007) Preparation of Artificial Seawater (ASW). Department of Environmental Protection, Florida, USA, SOP No. TA-03.02-5.10, pp. 1-2.

Mohammed A, Nehdi M and Adawi A (2008) Recycling waste latex paint in concrete with added value. ACI Materials Journal 105(4): 367-374.

Ramakrishhnan V (1992) Latex Modified Concretes and Mortars. Transportation Research Board National Research Council, Washington, DC, Synthesis of Highway Practice 179, pp. 31-35.

US EPA (United States Environmental Protection Agency) (1976) The Resource Conservation and Recovery Act 1976. Part 261: Hazardous Waste Regulation. US EPA, Washington, DC.

US EPA (United States Environmental Protection Agency) (1992) Test Method. Toxicity Characteristics Leaching Procedure. US EPA, Washington, DC, US EPA 8015 and 1311.

US EPA (United States Environmental Protection Agency) (2007) Test Method. Inductively Coupled Plasma-atomic Emission Spectrometry. US EPA, Washington, DC, SW846 6010C.

Yang G, Lee C and Hsiue G (1993) Properties of a mercurycontaining sludge solidified by polymer latex modified cementitious materials. Hazardous Waste and Hazardous Materials 10(4): 453-460.

Zampori L, Soraa IN, Pelosatoa R, Dotellib G and Stampinob PG (2006) Chemistry of cement hydration in polymer-modified pastes containing lead compounds. Journal of European Ceramic Society 26(4-5): 809-816.

\section{What do you think?}

To discuss this paper, please email up to 500 words to the editor at journals@ice.org.uk. Your contribution will be forwarded to the author(s) for a reply and, if considered appropriate by the editorial panel, will be published as a discussion in a future issue of the journal.

Proceedings journals rely entirely on contributions sent in by civil engineering professionals, academics and students. Papers should be 2000-5000 words long (briefing papers should be 1000-2000 words long), with adequate illustrations and references. You can submit your paper online via www.icevirtuallibrary.com/content/journals, where you will also find detailed author guidelines. 